Nikolayeva Lyudmila, $\mathrm{PhD}$ (Law Sciences), Professor, Kyiv National University of Trade and Economics, 19, Kyoto str., Kyiv, 02156, Ukraine

ORCID: 0000-0003-4710-0386

Sevastyanenko Olena,

Senior Lecturer, Kyiv National University of Trade and Economics, 19, Kyoto str., Kyiv, 02156, Ukraine

ORCID: 0000-0001-7260-7045

Korolkov Oleksiyi,

Senior Lecturer,

Kyiv National University of Trade and Economics, 19, Kyoto str., Kyiv, 02156, Ukraine

ORCID: 0000-0003-3436-1384

Researcher ID: D-2090-2019

\title{
LAW PROBLEMS IN BANKING (PROTECTION OF CONSUMER RIGHTS IN BANKING SERVICES)
}

Each person throughout his life uses certain services to meet his needs. The service is a result of work, whether or not there is or there isn't a material form in it.

In the process of building a democratic rule of law and becoming a market economy, it is important to provide, develop, improve and implement banking services, which in turn requires an improvement of the banking system in the state and the proper legal regulation of banking activities. Recently, it has undergone significant changes: the two-level banking system has been created, the activities of commercial banks and specialized lending and financial institutions are becoming more and more developed, the non-traditional areas of application of bank capital are expanding, and the nature of the relationship between banks and clients is changing.

Keywords: banking activity, banking system, banking operations, financial services, banking transactions, financial relationships.

Ніколаєва Людмила, Севастьяненко Олена, Корольков Олексій. Правові проблеми в банківській справі (захист прав споживачів у банківських послугах).

У статті розглянуто деякі проблеми правового захисту споживачів банківських послуг, проаналізовано поняття та види банківських послуг, їх види та рівні залежно від спрямованості щодо задоволення вимог клієнтів, нормативно 
правове регулювання даного виду послуг, зроблено конкретні пропозииії щодо вдосконалення наиіонального законодавства.

Ключові слова: банківська діяльність, банківська система, банківські операщиї, фінансові послуги, банківські операиії, фінансові відносини.

Relevance of the research topic. Banking system - it is a special type of economic activity which, without regulatory influence of the state, gathers signs of chaos, unpredictability, and leads to financial collapse. That is why state regulation of banking systems should be considered as a coherent system of relations between regulators and banking structures, the main peculiarities of which are a specific way of interconnection and interaction of its constituent elements.

Formulation of the problem. The banking industry is one of the fastest growing in the world economy. The banking sector of Ukraine did not bypass this process. Banking services are actively influencing the development of the Ukrainian economy at both macro and micro levels. First, banking is one of the active factors in the intensification of the reproduction process as a whole and its component as exchange, in particular. Second, banking services play a significant role in meeting the needs of the population, enhancing their standard of living by providing consumer loans and influencing small business development.

Currently, banking and banking services are in a state of active development and change, primarily due to the growing need for these services. Banking is certainly a specific area of social production by place in the process of public reproduction, the tasks they perform, the nature of the product, the mechanisms of organization and management.

Therefore, the definition of the term «banking service» in scientific circulation introduced several interpretations, which consist of the fact that «banking service» is both a type of activity, its result, and the activity itself. If you try to bring the above definitions to the common denominator, then you can offer the following: «banking service» - a regulated sequence of actions (transactions) carried out by the bank on the client's order, on the basis of payment, in order to meet the needs of the latter.

Using our definition as one of our research tools, we can classify banking services on the basis of certain criteria that characterize the features of their creation and provision to customers. Among them are, first of all, the orientation on market conditions. These will be traditional and innovative services.

Analysis of recent research and publications. Traditional services include credit, operating, investment $[7,52]$. Credit is a service related to providing the borrowers with the money in terms of their repayment, payment and timeliness. Operations are services in servicing payment documents, accepting deposits of legal entities and individuals, opening and maintaining current accounts of clients of transactions with currency values, providing guarantees and sureties of responsible storage, as well as renting safes for storing valuables and documents. Investment 
services consist in placing banks on their own behalf, on their own terms and at their own risk, attracted funds of legal entities and individuals. These include the services of banks for the organization of purchase and sale of securities on behalf of clients, the implementation of investments, authorized funds of other legal entities, etc.

Innovative services include services that were not previously inherent in banking: warranty, factoring, leasing, trust, advisory, information, etc. Guarantee services are performed by the bank on behalf and at the expense of the other party, on the basis of a return, if it is provided by the current legislation, or on the basis of a warrant established in the contract with the consent of the parties. Factoring services are provided by banks by acquiring the rights of claim for payment on financial liabilities purchased from different persons. Leasing services are provided by banks that purchase, at their own expense, suppliers of the means of production to lease them out to a long-term leasing company for the use of the property to their advantage. Trust (trust) services are services of banks on property management and performance of other services in interests and on behalf of clients.

Presenting main material. Being focused on meeting customer needs is another equally important criterion. The banking services for this classifier are divided into three levels:

1. The first level is the basic banking services that a customer actually buys. As a rule, they form the basic assortment of the bank: lending, servants on investment of capital, services in settlement and cash services, etc.

2. The second level is real-time banking services, ie the current assortment of the bank. This range is constantly evolving, without changing the basic directions of the bank's operation.

3. The third level is the extended banking services aimed at forming friendly relations with the client, providing him with versatile assistance (for example, servicing and developing foreign economic relations, developing the client's financial management).

The controversy over the definition of «banking service» makes it difficult to understand a category such as the banking market $[8,41]$. Being an element of a complex multilevel system of market relations, it functions as an independent formation with its own content and patterns of development. Taking into account the essence of the system forming part of this market (banking service), the market of banking services can be called the legislatively defined sphere of formation and realization of supply and demand for services of banks, which satisfy the needs of clients and generate banking profit.

The banking services market is a specific sphere of commodity relations, where transactions are performed in order to accumulate funds, provide loans, make cash payments, issue of money and securities, and foreign currency transactions.

The peculiarity of the banking services market is that it exists only in cash and has a direct dependence on the development of the markets it serves. As a rule, bank 
services are one-off, there is no possibility of their accumulation, they are not protected by patents.

The banking services market is characterized by all the inherent attributes of the market:

- banking services are the objects of the market;

- market entities are sellers of services: banks and buyers: individuals and legal entities, including the banks themselves;

- Price and sales channels.

Due to the impact of the global financial crisis, the banking business has changed somewhat, namely the change in the functioning of banking systems and the provision of their services. Speaking more specifically about banking services, some financial institutions (banks) began to provide poor quality services, and more specifically, services did not meet the needs of consumers and did not produce the desired result.

2015-2018 was marked by significant changes in the sphere of finance, adverse circumstances in the global financial markets affected each country. In Ukraine, this has led the actors of the relevant relationship, many banks and other financial institutions to take the path of compliance, and sometimes a clear violation of applicable law, to solve their financial problems. Moreover, this path intersected with the rights of ordinary citizens and legal entities - clients of such institutions [5].

State regulation of problems in the sphere of banking services is quite complicated due to the lack of a unified systematic legal act.

Therefore, the state regulation of the banking system of Ukraine should be aimed at creating a regulatory legal field of activity of commercial banks, such regulation would correspond to the current tendencies of banking activity; building a system of interconnections and interdependencies between public authorities in the implementation of fiscal and monetary policy; formation of competitiveness of the domestic banking system in the context of global integration processes; implementation of effective and timely supervision over compliance with the current banking legislation by Ukrainian banks; coordination of activities of state government structures in the external borrowing market.

Each of these areas of state regulation of the banking system of Ukraine requires special research. Let's take a closer look at the legislative and regulatory framework of domestic banks.

The legal framework for banking in Ukraine has begun to emerge since Ukraine's independence. Given the importance of banking regulation in ensuring stability in the development of the economy in Ukraine, there is a special banking legislation.

Banking law establishes the legal basis for bank lending, defines the legal position of credit institutions and the principles of their relations with credit recipients 
in terms of repayment, maturity and payment, as well as the basics of Ukraine's currency relations with foreign countries and rules of currency transactions in Ukraine.

The basis of banking legislation is the Constitution of Ukraine. All legislative and regulatory acts must be adopted taking into account the principles and provisions of the Basic Law of the State. It is such documents that form an adequate legal infrastructure in a state where the rule of law exists.

The legal infrastructure of banking regulation in Ukraine has three levels:

1) Legislation. In the absence of a single systematic legal act, the norms of which would regulate relationships arising in the field of banking, such as, for example, the Banking Code, banking legislation, are classified as general, such special. The general legislation includes the Law on Banks and Banking, the Laws of Ukraine that define the basic principles of activity of market entities, for example, the Law of Ukraine «On Business Companies», «On Securities and the Stock Market», the Law of Ukraine «On State regulation of the financial services market», the Law of Ukraine «On State Regulation of the Securities Market in Ukraine», the Law of Ukraine «On Investment Activity», the Law of Ukraine «On Prevention and Counteraction of Legalization» (Laundering) of Proceeds of Crime, etc $(2,3,4)$.

Special legislation is aimed at regulating the relationship between the entities of the banking services market. It includes the Law of Ukraine «On Banks and Banking Activities», the Law of Ukraine "On the National Bank of Ukraine», "On Mortgage Lending, Consolidated Mortgage Debt Transactions and Mortgage Certificates», the Law of Ukraine «On the Deposit Guarantee Fund of Individuals», the Law of Ukraine «On Payment Systems and Funds Transfer in Ukraine».

2) A series of regulatory rules. Regulations (by-laws) relate directly to the rules of banking that are developed by competent supervisory authorities. These include Cabinet of Ministers Resolutions, NBU Board Resolutions, Presidential Decrees. Examples include rules for capital adequacy regulation; the order of formation of obligatory reserves; rules for conducting currency transactions, etc.

3) Clarifications and comments on regulatory documents. It is an interpretation of a legal act that is provided by a supervisory authority to detail its actions on the application of legislation or regulations.

The domestic banking legislation is characterized by: the multilevel nature of the legal regulation of banking activities and the presence of a large number of by-laws; absence of a single codified act on banking; the dynamics of banking law, the constant introduction of changes and additions to regulations; the contradiction and complexity of many regulations, their inconsistency with the acts related to market management.

In society, largely due to the crisis, there is a growing awareness of this gap between the actual inequality and the legal «equality» of the bank and the client. For example, courts are increasingly siding with private borrowers, especially mortgages. By implementing intuitive rules of fairness, even in defiance of legal protections for 
contractual relations, judges seem to compensate for the weakness of the client's position. Courts, in a strange and paradoxical way, are beginning to fulfill the function of social protection, which is clearly overlooked in many aspects of the bank-client relationship.

Real protection of the rights of private clients is not so much to strengthen their positions by improving financial literacy (this is not possible), but to weaken their positions and limit the ability of banks.

The client is not at all obliged to be competent. He is obliged to pay, and literacy is a wish, but not a requirement. Therefore, customer illiteracy cannot be an excuse for banks.

During the crisis, many of the banks 'normal risks and many of the borrowers' abnormal risks were realized. And here is another grimace of the mythical «equality». Recognizing the losses as a result of the crisis, banks in their lobbying activities began to place special emphasis on their social importance, to protect the interests of depositors. And the banks, I must say, have received huge subsidies from the state in support of their social mission.

While citizens - first and foremost, borrowers - are left with their banking problems face to face. And because the main mass borrower was the «middle» class, politically amorphous, who does not visit polling stations and is not able to block the highways, so he did not receive any support from the state. The promises of mortgage loan restructuring are not taken into account - few have made use of this opportunity. And the problem is much wider.

Human rights, legislative, legal and public opinion is gradually but steadily focusing on this issue. In the near future, banks are likely to have to accept a number of restrictions and spend on compensation for their dominant role in public relations. This is not politicking, nor the grimace of the crisis, it is not even populism. This is an objective trend and an inevitability that bankers need to prepare for right now.

Of course, banks' responsibility should be increased. But the process must be progressive and two-sided. And when it comes to, for example, banning banks from unilaterally changing lending rates, we also need to simplify for banks, say, the circulation of collateral. This, again, will allow banks to offer better conditions to citizens.

If we do not adhere to such a balanced approach that takes into account the interests of both banks and customers, and impose only restrictions on banks, then all measures to strengthen their responsibility will necessarily be reflected in the cost of banking services.

Special protection and regulation are already in place to protect consumers of banking services in the banking sector. But now these procedures are applied by the state almost exclusively for the purpose of economic, monetary regulation and fight against shadow financial turnover. The trend of violent socialization of the banking business will inevitably lead to the emergence of new social constraints and 
regulations - in addition to what has already been done by the deposit insurance system.

Much has already been done in this direction. These include interfering with the banking activities of government officials, introducing mandatory disclosure of effective interest rates on loans, and restrictions on the distribution of credit cards.

In most «network» banks, the client can only manage their contribution in the branch where he / she has contributed. Then can such a structure be called a network?

If a bank is advertised as a network, then its network is considered as a factor of cost, as an advantage, for example, in terms of access in any corner of the country. But for the benefit of a single network to become a real consumer value, there must be equal conditions and equal responsibility for the «sister daughters» of the same name.

In the long term, this rule should be introduced at the transnational level. If a bank collects clients and money under its international brand, then any «daughter» of this bank around the world must provide services on the same terms as in the country where the client was registered. Or, it should be denied the right to use a transnational brand and abandon the promises of reliability.

Now the use of «daughters» of their parent international brands without localization is often a deception of consumers, because brand «mothers» on the obligations of «daughters» may not meet or offer other conditions.

To protect the consumers of banking services, an All-Ukrainian Public Organization for the Protection of Consumers of Financial Services was created. The priority area of its activity is the provision of free legal support to depositors of banks, investment funds, credit unions, clients of insurance companies and construction financing funds.

There is also an Association of Ukrainian Banks on the territory of Ukraine, which has announced that it has decided to set up an All-Ukrainian Coordination Council for Creditors, Investors and Investors. The purpose of the council is to intensify the dialogue between banks and depositors and to increase trust between them. The Coordinating Council should also promote the introduction of positive experience of associations of depositors to protect the rights and interests of consumers of banking products.

Conclusion: Therefore, in order to ensure the conditions for alignment of the basic principles of the integration development of the domestic banking system to world standards, it is advisable to implement a system of consistent legal measures, covering:

- conducting large-scale studies of the NBU regulatory acts on their compliance with the current legislation. According to the results of the analysis, to develop a mechanism for their harmonization, while avoiding double standards;

- systematization of existing legislative and regulatory legal documents into a single codified act - the Banking Code; 
- providing banks with the legal framework for regulating banks' activities with signs of stability and predictability of development;

- developing banking legislation to ensure an adequate level of corporate governance in Ukrainian banks.

- Improvement of existing legislation on: organization of banking supervision; application of monetary policy instruments, protection of creditors' rights; participation of banks in the stock market; and the development of legal provisions for the activities of foreign bank branches in Ukraine.

\section{REFERENCES}

1. Constitution of Ukraine: Law of Ukraine of June 28, 1996 No. 254k / 96-BP URL: http://zakon.rada.gov.ua/laws/show/254\%D0\%BA/96-\%D0\%B2\%D1\%80.

2. Hospodarskyy kodeks Ukrayiny : Zakon Ukrayiny vid 16 sichnya 2003 r. // Ofitsiynyy visnyk Ukrayiny. 2003. № 11. St. 462.

3. Podatkovyy kodeks Ukrayiny: Zakon Ukrayiny vid 2 hrudnya 2010 r. // Vidomosti Verkhovnoyi Rady Ukrayiny (VVR), 2011, № 13-14, № 15-16, № 17, St.112.

4. «Pro banky i bankivsku diyalnist» Zakon Ukrayiny vid 7 hrudnya $2000 \mathrm{r}$. № 2121-III. http://rada.gov.ua

5. Pro Zahalnoderzhavnu prohramu adaptatsiyi zakonodavstva Ukrayiny do zakonodavstva Yevropeys'koho Soyuzu : Zakon Ukrayiny vid 18 bereznya 2004 r. № 1629-IV // Ofitsiynyy visnyk Ukrayiny. 2004. № 25 (30.04.2004). St. 1028.

6. Bankivstke pravo: pidruchnyk [dlya studentiv zakladiv vyshchoyi osvity, slukhachiv aspirantury ta kursiv pidvyshchennya kvalifikatsiyi] / [O.V. Baklan, YE.P. Hayvorons'kyy, V.O. Timashov, T.O. Hurzhiy, O.V. Korolkov, YU.YU. Pustovit] ; za red. YE.P. Hayvoronskoho. K.: Drukarsyy dvir Oleha Fedorova, 2018. $346 \mathrm{p}$.

7. Orlyuk O. P. Bankivske pravo : navch. posib. / O. P. Orlyuk ; MON Ukrayiny. 2.vyd., pererob. i dop. K. : Yurinkom Inte, 2006. 392 p. 